\title{
STUDI KADAR NITRAT DAN FOSFAT PERAIRAN RAWA BANJIRAN DESA SEDANG KECAMATAN SUAK TAPEH KABUPATEN BANYUASIN
}

\author{
Study of Nitrate and Phosfhate Levels in The Swamp Flood Waters in Sedang Village, \\ Subdistrict Suak Tapeh, District Banyuasin \\ Ramadhan $^{1}$, Indah Anggraini Yusanti ${ }^{2 *}$, \\ ${ }^{1}$ Balai Perikanan Budidaya Air Tawar Sungai Gelam, Jambi \\ ${ }^{2}$ Program Studi Ilmu Perikanan Fakultas Perikanan Universitas PGRI Palembang \\ *Corresponding author : indahayusanti@gmail.com
}

\begin{abstract}
ABSTRAK
Aktivitas yang terjadi di perairan rawa banjiran Desa Sedang Kecamatan Suak Tapeh Kabupaten Banyuasin menghasilkan limbah buangan dan mengakibatkan perairan tersebut menjadi tercemar. Masuknya limbah buangan tersebut menyebabkan menurunnya kualitas perairan yang ditandai dengan kenaikan konsentrasi zat hara. Zat hara yang umum di lingkungan perairan adalah nitrat dan fosfat. Penelitian ini dilakukan di rawa banjiran Desa Sedang Kecamatan Suak Tapeh Kabupaten Banyuasin. Sampling kualitas air dilakukan pada Agustus 2016, Juni 2017 dan April 2018 di 3 (tiga) stasiun pengamatan, yaitu stasiun 1 Rawa Nebong Kuning, stasiun 2 Rawa Poron dan stasiun 3 Rawa Banan. Hasil penelitian ini mengindikasikan bahwa keberadaan kadar nitrat dan fosfat di rawa banjiran Desa Sedang Kecamatan Suak Tapeh Kabupaten Banyuasin termasuk dalam kriteria perairan eutrofik.
\end{abstract}

Kata Kunci: Nitrat, Fosfat, Status Tropis Perairan, Rawa Banjiran

\begin{abstract}
Activities that occur in the swamp flooding waters of the medium village of Suak Tapeh Subdistrict, Banyuasin District, produce waste and cause the waters to become polluted. The entry of waste water causes a decrease in the quality of the waters which is characterized by an increase in nutrient concentrations. Common nutrients in the aquatic environment are nitrates and phosphates. This research was carried out in the swamp flooding of Medium Village of Suak Tapeh District, Banyuasin Regency. Water quality sampling was conducted in August 2016, June 2017 and April 2018 in 3 (three) observation stations, namely Station 1 Rawa Nebong Kuning, Station 2 Rawa Poron and Station 3 Rawa Banan. The results of this study indicate that the presence of nitrate and phosphate levels in The Swamp Flood Waters in Sedang Village, Subdistrict Suak Tapeh, District Banyuasin is included in the eutrophic waters criteria.
\end{abstract}

Keywords: Nitrate, Phosphate, Aquatic Tropic Status, Flood Swamp 


\section{PENDAHULUAN}

Rawa Banjiran Desa Sedang Kecamatan Suak Tapeh Kabupaten Banyuasin terdiri dari 3 (tiga) rawa yaitu rawa nebong kuning yang memiliki luas $84.000 \mathrm{~m}^{2}$, rawa poron dengan luasan $41.800 \mathrm{~m}^{2}$ dan rawa banan dengan luas $31.200 \mathrm{~m}^{2}$ (Haryani, 2014 dalam Yusanti et al, 2018). Rawa banjiran ini merupakan kawasan perairan yang ketersediaan airnya dipengaruhi oleh air sungai dan air hujan. Keberadaan rawa banjiran sangat penting karena memiliki potensi nilai ekonomi dan ekologis yang tinggi untuk mendukung kehidupan masyarakat setempat (Yusanti, 2017).

Aktifitas masyarakat disekitar rawa banjiran adalah memanfaatkan air rawa untuk kegiatan rumah tangga, pertanian, perikanan dan rekreasi. Padatnya aktivitas manusia yang terjadi di perairan tersebut mengakibatkan perairan ini menghasilkan limbah buangan dan mengakibatkan perairan tersebut menjadi tercemar. Masuknya limbah buangan tersebut menyebabkan menurunnya kualitas perairan yang ditandai dengan kenaikan konsentrasi zat hara.

Menurut Fachrul et al. (2005) dalam Utami (2016), zat hara merupakan unsur yang diperlukan dan mempunyai pengaruh terhadap proses dan perkembangan hidup organisme. Zat hara yang yang biasa dijadikan indikator lingkungan perairan adalah nitrat dan fosfat. Simanjuntak (2012) dalam Patty et al. (2015) mengatakan bahwa sumber utama zat hara nitrat dan fosfat berasal dari perairan itu sendiri yaitu melalui proses-proses penguraian pelapukan ataupun dekomposisi tumbuh-tumbuhan dan sisa-sisa organisme mati. Effendi (2003) juga menambahkan bahwa nitrat dan fosfat dalam keadaan normal merupakan sumber nutrien utama bagi pertumbuhan tanaman dan alga. Nitrat berfungsi sebagai pengontrol produktivitas primer perairan di zona eufotik dan dapat menjadi pupuk pada tanaman air. Kedua unsur ini memiliki peran vital bagi pertumbuhan fitoplankton atau alga yang biasa digunakan sebagai indikator kualitas air dan tingkat kesuburan suatu perairan. Lebih lanjut, Davis dan Cornwell dalam Effendi (2003) mengatakan bahwa fosfat merupakan bentuk fosfor yang berfungsi sebagai unsur esensial bagi tumbuhan tingkat tinggi dan alga, sehingga unsur ini menjadi faktor pembatas bagi tumbuhan dan alga akuatik serta mempengaruhi tingkat produktivitas perairan.

Berdasarkan uraian diatas, maka perlu dilakukan penelitian untuk mengetahui kondisi terkini dari konsentrasi nitrat dan fosfat yang terkandung dalam perairan Rawa Banjiran Desa Sedang Kecamatan Suak Tapeh Kabupaten Banyuasin yang dapat dijadikan sebagai informasi dan acuan dalam upaya monitoring kualitas air, terutama tingkat kesuburan perairannya.

\section{BAHAN DAN METODE}

Penelitian ini dilakukan pada bulan Agustus 2016, Juni 2017 dan April 2018, berlokasi di Rawa Banjiran Desa Sedang Kecamatan Suak Tapeh Kabupaten Banyuasin. Pengukuran kualitas air dilakukan di lapangan dan di Laboratorium Balai Riset Perikanan Perairan Umum Daratan dan Penyuluh Perikanan Palembang.

Alat yang dipergunakan pada penelitian ini meliputi botol sampel, kotak penyimpanan sampel, termometer $\mathrm{Hg}$, secchi disk, tongkat pengukur kedalaman air, $\mathrm{pH}$ meter, perahu, sedangkan bahan yang digunakan adalah bahan-bahan kimia dan air rawa banjiran yang berasal dari Desa Sedang Kecamatan Suak Tapeh Kabupaten Banyuasin.

Penelitian ini menggunakan metode Purposive Random Sampling. Dilakukan 
di 3 (tiga) stasiun pengambilan sampling, yaitu stasiun 1 Rawa Nebong Kuning (merupakan daerah padat penduduk), stasiun 2 Rawa Poron (merupakan daerah tidak padat penduduk) dan stasiun 3 Rawa Banan (merupakan daerah tidak padat penduduk).

Pengambilan sampel air rawa banjiran dilakukan pada jam 08.00 sampai dengan selesai. Parameter pengujian tersebut meliputi parameter fisika, yaitu suhu, kecerahan dan kedalaman air, sedangkan parameter kimia meliputi $\mathrm{pH}$, DO, amoniak, nitrat dan fosfat. Selanjutnya status kesuburan perairan di rawa banjiran ditentukan berdasarkan hasil pengujian kualitas air nitrat dan fosfat. Penentuan tingkat kesuburan perairan rawa banjiran berdasarkan parameter nitrat dan fosfat mengacu pada Goldman dan Horne (1983) dalam Zulfia dan Aisyah (2013), dan Vollenweider dalam Zulfia dan Aisyah (2013).

\section{HASIL DAN PEMBAHASAN}

Hasil pengujian terhadap kualitas air perairan rawa banjiran Desa Sedang Kecamatan Suak Tapeh Kabupaten Banyuasin disajikan pada Tabel 1 berikut ini.

Tabel 1. Hasil Pengujian Kualitas Air Perairan Rawa Banjiran Desa Sedang Kecamatan Suak Tapeh Kabupaten Banyuasin.

\begin{tabular}{|c|c|c|c|c|c|c|c|c|c|}
\hline \multirow{3}{*}{ Parameter } & \multicolumn{9}{|c|}{ Stasiun Pengamatan } \\
\hline & \multicolumn{3}{|c|}{ Rawa Nebong Kuning } & \multicolumn{3}{|c|}{ Rawa Poron } & \multicolumn{3}{|c|}{ Rawa Banan } \\
\hline & $\begin{array}{c}\text { Agustus } \\
2016 \\
\end{array}$ & $\begin{array}{l}\text { Juni } \\
2017\end{array}$ & $\begin{array}{c}\text { April } \\
2018\end{array}$ & $\begin{array}{c}\text { Agustus } \\
2016 \\
\end{array}$ & $\begin{array}{l}\text { Juni } \\
2017 \\
\end{array}$ & $\begin{array}{c}\text { April } \\
2018\end{array}$ & $\begin{array}{c}\text { Agustus } \\
2016\end{array}$ & $\begin{array}{l}\text { Juni } \\
2017 \\
\end{array}$ & $\begin{array}{c}\text { April } \\
2018\end{array}$ \\
\hline Suhu $\left({ }^{\circ} \mathrm{C}\right)$ & 29 & 28 & 30 & 28 & 28 & 29 & 28 & 29 & 28 \\
\hline $\begin{array}{l}\text { Kedalaman } \\
\text { air }(\mathrm{m})\end{array}$ & $2,5-4$ & $2,5-4$ & $2,5-4$ & $2,3-3$ & $2,3-3$ & $\begin{array}{l}2,3- \\
3 \mathrm{~m}\end{array}$ & $2-3,8$ & $2-3,8$ & $2-3,8$ \\
\hline $\begin{array}{l}\text { Kecerahan } \\
(\% \text { oo) }\end{array}$ & 29 & 29 & 28 & 30 & 30 & 29 & 27 & 27 & 27 \\
\hline $\mathrm{pH}$ & 8,1 & 8,1 & 7,9 & 8,1 & 8,0 & 7,9 & 8,3 & 7,9 & 8,0 \\
\hline Oksigen & 6,4 & 5,3 & 5,2 & 6,6 & 4 & 5,1 & 6,5 & 4,7 & 5,5 \\
\hline Terlarut (mg/1) & & & & & & & & & \\
\hline Amoniak (mg/l) & 0,16 & 0,18 & 0,16 & 0,16 & 0,09 & 0,12 & 0,19 & 0,18 & 0,18 \\
\hline Nitrat $(\mathrm{mg} / \mathrm{l})$ & 0,04 & 0,06 & 0,06 & 0,55 & 0,55 & 0,60 & 0,60 & 0,67 & 0,65 \\
\hline Fospat (mg/l) & 0,15 & 0,16 & 0,18 & 1,18 & 1,19 & 1,18 & 0,85 & 0,97 & 0,90 \\
\hline
\end{tabular}

Berdasarkan Tabel 1 di atas, dapat diketahui bahwa kondisi suhu pada stasiun 1 Rawa Nebong Kuning pada setiap bulan pengamatan berkisar antara $28^{\circ} \mathrm{C}$ hingga $30^{\circ} \mathrm{C}$, sedangkan untuk stasiun 2 Rawa Poron dan stasiun 3 Rawa Banan berkisar antara $28^{\circ} \mathrm{C}$ hingga $29^{\circ} \mathrm{C}$. Nilai suhu yang diperoleh masih termasuk dalam kisaran suhu yang optimum untuk menunjang kehidupan biota di perairan rawa banjiran, diantaranya adalah fitoplankton sebagai sumber makanan dan ikan-ikan yang hidup di perairan rawa banjiran tersebut. Hal ini sesuai dengan pernyataan Effendi (2003) yang menyatakan bahwa kisaran suhu yang optimum untuk pertumbuhan fitoplankton di perairan adalah $20^{\circ} \mathrm{C}-$ $30^{\circ} \mathrm{C}$. Selain itu, Diantari, $d k k$ (2018) menambahkan bahwa ikan yang hidup pada perairan rawa-rawa pada suhu antara $25-32^{\circ} \mathrm{C}$ dapat tumbuh dengan baik. Lebih lanjut dinyatakan oleh Kordi (2000) bahwa perubahan pada suhu dipengaruhi oleh parameter lainnya, diantaranya musim, cuaca, waktu pengukuran, kedalaman air serta kecerahan suatu perairan. Nurdin (2000) dalam Efrizal (2006) juga menambahkan bahwa suhu dapat mempengaruhi fotosintesis baik secara langsung maupun tidak langsung. Pengaruh secara langsung untuk mengontrol reaksi enzimatik dalam proses 
fotosintesis, dimana suhu yang tinggi dapat menaikan laju maksimum fotosintesis, sedangkan pengaruh tidak langsung berperan dalam merubah struktur hidrologi kolam perairan yang akan mempengaruhi distribusi fitoplankton.

Kedalaman air rawa banjiran untuk stasiun 1 Rawa Nebong Kuning tiap bulan pengamatan berkisar antara $2.5 \mathrm{~m}$ hingga $4 \mathrm{~m}$, sedangkan stasiun 2 Rawa Poron berkisar $2.3 \mathrm{~m}$ hingga $3 \mathrm{~m}$ dan stasiun 3 Rawa Banan berkisar $2 \mathrm{~m}$ hingga $3.8 \mathrm{~m}$. Kisaran nilai kedalaman air yang didapatkan masih memenuhi persyaratan untuk menunjang kehidupan biota di perairan rawa banjiran. Hal ini sesuai dengan pendapat Kordi (2013) dalam Diantari (2018) yang menyatakan bahwa nilai optimum untuk kedalaman perairan adalah sekitar $1.5 \mathrm{~m}$ sampai dengan $8 \mathrm{~m}$. Lebih lanjut Sari (2011) dalam Haris (2018) menambahkan bahwa, perairan dengan kedalaman air yang terlalu dekat dengan dasar sangat rentan terhadap sedimentasi penumpukan kotoran dari sisa pakan dan hasil metabolisme ikan.

Nilai kecerahan air untuk stasiun 1

Rawa Nebong Kuning berkisar $28 \mathrm{~cm}$ hingga $29 \mathrm{~cm}$, stasiun 2 Rawa Poron berkisar $29 \mathrm{~cm}$ hingga $30 \mathrm{~cm}$ dan stasiun 3 Rawa Banan adalah $27 \mathrm{~cm}$. Kecerahan tertinggi didapatkan pada stasiun 2 Rawa Poron. Hal ini memungkinkan masuknya cahaya matahari secara optimal ke dalam perairan. Sedangkan nilai terendah diperoleh pada stasiun 3 rawa banan, yaitu sebesar $27 \mathrm{~cm}$. Rendahnya kecerahan diduga karena adanya aktifitas di perairan tersebut. Selain itu faktor kedalaman rawa juga berpengaruh terhadap nilai kecerahan pada perairan, dimana semakin tinggi tingkat kecerahan maka pertumbuhan fitoplankton yang ada di perairan akan meningkat karena semakin banyak cahaya matahari yang masuk ke dalam perairan yang mendorong fitoplankton untuk aktif berfotosintesis. Menurut Zulfia dan
Aisyah (2013), nilai kecerahan tergantung dengan keadaan cuaca, waktu pengukuran, warna air, kekeruhan dan padatan tersuspensi yang ada didalam perairan.

Nilai pH pada stasiun 1 Rawa Nebong Kuning berkisar 7.9 hingga 8.1, pada stasiun 2 Rawa Poron berkisar 7.9 hingga 8.0 dan pada stasiun 3 Rawa Banan berkisar 7.9 hingga 8.3. Menurut Isnansetyo dan Kurniastuty (1995) dalam Efrizal (2006), nilai $\mathrm{pH}$ berkisar 8.0 hingga 9.0 masih dapat mendukung perkembangan plankton. Selain itu menurut Effendi (2003), sebagian besar biota akuatik sensitive terhadap perubahan $\mathrm{pH}$ dan menyukai nilai $\mathrm{pH}$ sekitar antara 7 hingga 8.5. Dengan demikian $\mathrm{pH}$ yang terdapat pada ke 3 (tiga) stasiun pengamatan tersebut masih dapat mendukung kehidupan biota di rawa banjiran Desa Sedang kecamatan Suak Tapeh Kabupaten Banyuasin.

Kondisi oksigen terlarut (DO) pada stasiun 1 Rawa Nebong kuning berkisar antara 5.2 hingga 6.4. Untuk stasiun 2 Rawa Poron nilai oksigen terlarut berkisar antara 4 hingga 6.6 dan stasiun 3 Rawa Banan berkisar antara 4.7 hingga 6.5 . Menurut Siagian (2009), kandungan oksigen terlarut sangat berperan dalam menentukan organisme hidup di perairan. Oksigen diperlukan organisme akuatik untuk mengoksidasi nutrien yang masuk ke dalam tubuh. Oksigen yang terdapat dalam perairan berasal dari hasil fotosintesis organisme akuatik berklorofil dan juga difusi dari atmosfer. Peningkatan difusi yang berasal dari oksigen ke dalam perairan dapat dibantu oleh angin. Sejalan dengan hal tersebut, Simarmata (2015) menambahkan bahwa konsentrasi oksigen terlarut di perairan berkaitan dengan fitoplankton sebagai penghasil oksigen melalui proses fotosintesis. Sumber utama oksigen di kolam dan danau berasal dari difusi atmosfir dan fotosintesis. Difusi dari atmosfir ke perairan adalah proses 
yang sangat lambat, sehingga sumber utama oksigen di perairan danau adalah hasil proses fotosintesis.

Kisaran nilai amoniak pada stasiun 1 Rawa Nebong Kuning adalah berkisar antara $0.16 \mathrm{mg} / \mathrm{L}$ hingga $0.18 \mathrm{mg} / \mathrm{L}$, pada stasiun 2 Rawa Poron adalah $0.09 \mathrm{mg} / \mathrm{L}$ hingga $0.16 \mathrm{mg} / \mathrm{L}$, sedangkan stasiun 3 Rawa Banan adalah $0.18 \mathrm{mg} / \mathrm{L}$ hingga $0.19 \mathrm{mg} / \mathrm{L}$. Berdasarkan PP RI No. 82 Tahun 2001 tentang Pengelolaan Kualitas Air dan Pengendalian Pencemaran Air, dijelaskan bahwa kandungan amoniak untuk kegiatan perikanan adalah $<0.02$ $\mathrm{mg} / \mathrm{L}$. Dari hasil uji laboratorium menunjukkan bahwa ke-3 (tiga) stasiun tersebut memiliki nilai amoniak di atas ambang batas maksimum ketentuan baku mutu. Tingginya nilai amoniak ini diduga karena adanya aktifitas penduduk disekitar perairan rawa banjiran tersebut. Haris (2019) menyatakan bahwa amoniak dalam perairan dapat berasal dari bahanbahan organik dan pengeluaran hasil dari metabolisme ikan melalui ginjal dan jaringan insang, selain itu amoniak yang terdapat dalam keramba, tambak atau perairan dapat pula terbentuk sebagai hasil proses dekomposisi protein yang berasal dari sisa pakan atau plankton yang mati. Apabila proses pembusukan (nitrifikasi) tidak berlangsung lancar maka terjadi pembusukan amoniak sampai pada konsentrasi yang membahayakan ikan.

Nilai nitrat yang terkandung di stasiun 1 Rawa Nebong Kuning adalah sebesar $0.04 \mathrm{mg} / \mathrm{L}$ hingga $0.06 \mathrm{mg} / \mathrm{L}$, pada stasiun 2 Rawa Poron sebesar $0.55 \mathrm{mg} / \mathrm{L}$ hingga $0.60 \mathrm{mg} / \mathrm{L}$ sedangkan pada stasiun 3 Rawa Banan sebesar $0.60 \mathrm{mg} / \mathrm{L}$ hingga $0.67 \mathrm{mg} / \mathrm{L}$. Nilai nitrat yang diperoleh masih berada di bawah standar nilai yang disyaratkan dalam PP No. 82 tahun 2001, yaitu $10 \mathrm{mg} / \mathrm{L}$ untuk penggunaan kelas I (air minum dan peruntukan lain dengan mutu yang disyaratkan sama) dan kelas II (rekreasi air, budidaya, pertanaman) serta $20 \mathrm{mg} / \mathrm{L}$ untuk penggunaan kelas III (budidaya, pertanaman) dan kelas IV (pertanaman dan peruntukan lain dengan mutu yang disyaratkan sama). Secara umum, menurut Wetzel (2001) dalam Zulfia dan Aisyah (2013) nilai konsentrasi nitrat di perairan dalam kondisi baik (belum terkontaminasi polusi) karena berada pada kisaran rendah bahkan tidak terdeteksi hingga mencapai $10 \mathrm{mg} / \mathrm{L}$.

Nitrat adalah bentuk utama nitrogen di perairan dan merupakan nutrien utama yang dibutuhkan bagi pertumbuhan tanaman dan algae. Nitrat sangat mudah larut dalam air dan bersifat stabil (Bahri, 2006 dalam Amien, 2015). Sumber utama pengkayaan zat hara nitrat adalah run off, erosi, leaching lahan pertanian yang subur, dan limbah permukiman. Kadar nitrat pada perairan alami biasanya tidak pernah melebihi nilai $0.1 \mathrm{mg} / \mathrm{L}$. Kadar nitrat di perairan mencapai nilai $0.2 \mathrm{mg} / \mathrm{L}$ dapat menyebabkan eutrofikasi yang berakibat pada tumbuh pesatnya fitoplankton dan alga. Terjadinya pencemaran antropogenik dapat digambarkan apabila kadar nitrat di perairan lebih dari $5 \mathrm{mg} / \mathrm{L}$ (Davis dan Cornwell, 1991 dalam Effendi, 2003).

Mengacu pada Goldman dan Horne (1983) dalam Zulfia dan Aisyah (2013) mengenai klasifikasi status tropik berdasarkan nilai nitrat di perairan terdiri dari 3 kriteria status tropik yaitu kadar nitrat $<0.1 \mathrm{mg} / \mathrm{L}$ untuk perairan oligotrofik; kadar nitrat antara $0,1 \mathrm{mg} / \mathrm{L}$ hingga $0.2 \mathrm{mg} / \mathrm{L}$ untuk perairan mesotrofik; dan kadar nitrat $>0.2 \mathrm{mg} / \mathrm{L}$ untuk perairan eutrofik. Berdasarkan kriteria tersebut, stasiun 1 Rawa Nebong Kuning dengan nilai nitrat sebesar 0.04 $\mathrm{mg} / \mathrm{L}$ hingga $0.06 \mathrm{mg} / \mathrm{L}$ termasuk dalam kategori status tropik oligotrofik. Untuk stasiun 2 Rawa Poron dan stasiun 3 Rawa Banan dengan nilai nitrat sebesar 0.55 $\mathrm{mg} / \mathrm{L}$ hingga $0.60 \mathrm{mg} / \mathrm{L}$ dan $0.60 \mathrm{mg} / \mathrm{L}$ hingga $0.67 \mathrm{mg} / \mathrm{L}$, termasuk dalam kriteria status tropik eutrofik. 
Nilai fosfat yang terkandung pada stasiun 1 Rawa Nebong Kuning berkisar $0.15 \mathrm{mg} / \mathrm{L}$ hingga $0.18 \mathrm{mg} / \mathrm{L}$. Pada stasiun 2 Rawa Poron berkisar antara 1.18 $\mathrm{mg} / \mathrm{L}$ hingga $1.19 \mathrm{mg} / \mathrm{L}$ dan stasiun 3 Rawa Banan berkisar antara $0.85 \mathrm{mg} / \mathrm{L}$ hingga $0.97 \mathrm{mg} / \mathrm{L}$. Berdasarkan Peraturan Pemerintah No. 82 Tahun 2001, nilai total fosfat berkisar $0.2 \mathrm{mg} / \mathrm{L}$ hingga $1 \mathrm{mg} / \mathrm{L}$. Dapat dilihat bahwa nilai fosfat di perairan melebihi ambang batas yang ditentukan. Menurut Effendi (2003), fosfat tidak bersifat toksik bagi manusia, hewan dan ikan. Keberadaan fosfat di perairan sangat penting terutama berfungsi dalam pembentukan protein dan metabolisme bagi organisme. Namun tingginya fosfat dikhawatirkan dapat menyebabkan terjadinya eutrofikasi berupa ledakan jumlah Algae (blooming) yang berakibat buruk bagi budidaya perikanan. Sumber fosfat di perairan berasal dari limbah peternakan, limbah manusia terutama detergen, pertanian terutama penggunaan pupuk anorganik seperti TSP (Triple Super Phosphat), limbah industri serta dari proses alamiah di lingkungan itu sendiri (Fried et al. 2003 dalam Zulfia dan Aisyah, 2013).

Menurut Vollenweider dalam Effendi (2003), klasifikasi status tropik fosfat di perairan terdiri dari 3 kriteria yaitu kadar fosfat berkisar antara 0.003 $\mathrm{mg} / \mathrm{L}$ hingga $0.01 \mathrm{mg} / \mathrm{L}$ untuk perairan oligotropik; kadar fosfat $0,011 \mathrm{mg} / \mathrm{L}$ hingga $0,03 \mathrm{mg} / \mathrm{L}$ untuk perairan mesotrofik; dan kadar fosfat $0,031 \mathrm{mg} / \mathrm{L}$ hingga $0,1 \mathrm{mg} / \mathrm{L}$ untuk perairan eutrofik. Berdasarkan kriteria tersebut, stasiun 1 Rawa Nebong Kuning, stasiun 2 Rawa Poron dan stasiun 3 Rawa Banan termasuk dalam kategori status tropik eutrofik.

\section{SIMPULAN}

Berdasarkan hasil penelitian, dapat disimpulkan bahwa nilai nitrat dan fosfat yang terdapat di perairan rawa banjiran Desa Sedang Kecamatan Suak Tapeh Kabupaten Banyuasin termasuk dalam kategori perairan yang eutrofik.

\section{DAFTAR PUSTAKA}

Amien, M.H., 2015. Studi Kadar Nitrat Dan Fospat Di Perairan Pesisir Kota Tarakan, Kalimantan Utara. Jurnal Harpodon Borneo. Vol. 8 (1). Hlm: 27-34. DOI: https://doi.org/10.35334/harpodon. $\underline{\mathrm{v} 8 \mathrm{i} 1.123}$

Diantari, R., Damai, A. A., dan Pratiwi, L. D. 2018. Evaluasi Kesesuaian Perairan Untuk Budidaya Ikan Betutu (Oxyeleotris marmorata Bleeker, 1852) Di Desa Rantau Jaya Makmur Sungai Way Pegadungan Kecamatan Putra Rumbia Kabupaten Lampung Tengah. Jurnal Rekayasa dan Teknologi Budidaya Perairan. Vol. 7 (1). Hlm : 807-822

Effendi, H. 2003. Telaah Kualitas Air bagi Pengelolaan Sumber Daya Lingkungan Perairan. Kanisius. Yogyakarta. 243 p.

Efrizal, T. 2006. Hubungan Beberapa parameter Kualitas Air dengan Kelimpahan Fitoplankton di Perairan Pulau Penyengat Kota Tanjung Pinang Provinsi Kepulauan Riau. Fakultas Ilmu Kelautan dan Perikanan Maritim. Universitas Raja Ali Haji. Tanjung Pinang

Haris, R.B.K., dan Yusanti, I.A. 2018. Studi Parameter Fisika Kimia Air Untuk Keramba Jaring Apung Di Kecamatan Sirah Pulau Padang Kabupaten Ogan Komering Ilir Provinsi Sumatera Selatan. Jurnal 
Ilmu-ilmu Perikanan dan Budidaya Perairan. Vol.14(2). Hlm : 57-62. DOI: http://dx.doi.org/10.31851/jip bp.v13i2.2434

Haris, R.B.K., dan Yusanti, I.A. 2019. Analisis Kesesuaian Perairan Untuk Keramba Jaring Apung Di Kecamatan Sirah Pulau Padang Kabupaten Ogan Komering Ilir Provinsi Sumatera Selatan. Jurnal Lahan Suboptimal. Vol. 8 (1). Hlm : 20-30.

DOI: https://doi.org/10.33230/JLSO $\underline{8.1 .2019 .356}$

Kordi, K. 2000. Parameter Kualitas Air. Karya Anda. Ujung Pandang. 55hlm

Patty, S.I., Arfah, H., dan Malik S. Abdul, M.A. 2015. Zat Hara (Fosfat, Nitrat), Oksigen Terlarut dan $\mathrm{pH}$ Kaitannya Dengan Kesuburan Di Perairan Jikumerasa, Pulau Buru. Jurnal Pesisir dan Laut Tropis. Vol. 1 (1). Hlm : 43-50.

Simarmata, A.H. dan Siagian, M. 2015. Profil Vertikal Oksigen Terlarut di Danau Oxbow Pinang Dalam, Desa Buluh Cina-Siak Hulu, Kabupaten Kampar, Provinsi Riau. Jurnal Akuatika. Vol. 6 (1). Hlm : 87-94.

Utami, T. M. R., Maslukah, L., dan Yusuf, M. 2016. Sebaran Nitrat (NO3) dan Fosfat (PO4) Di Perairan Karangsong Kabupaten Indramayu. Buletin Oseanografi Marina. Vol. 5 (1). Hlm : 31-37

Yusanti, I.A., dan Widayatsih, T. 2017. Keanekaragaman Fitoplankton Di Rawa Banjiran Desa Sedang Kecamatan Suak Tapeh Kabupaten Banyuasin. Prosiding Lahan Suboptimal. Hlm : 412-219
Yusanti, I.A., Widayatsih, T., dan Ramadhan. 2018. Keanekaragaman Zooplankton Di Rawa Banjiran Desa Sedang Kecamatan Suak Tapeh Kabupaten Banyuasin. Jurnal Biota. Vol. 4 (1) : 7-11 DOI : https://doi.org/10.19109/Biota.v4i1. $\underline{1435}$

Zulfia, N dan Aisyah. 2013. Status Trofik Perairan Rawa Pening Ditinjau Dari Kandungan Unsur Hara $\left(\mathrm{NO}_{3}\right.$ Dan $\mathrm{PO}_{4}$ ) Serta Klorofil-a. Jurnal Bawal. Vol. 5 (3). Hlm : 189-199. 